REVIEW ARTICLE

\title{
Repurposing of Acriflavine to Target Chronic Myeloid Leukemia Treatment
}

\author{
Rawan Nehme ${ }^{1,2,3, \#}$, Rawan Halla1 ${ }^{1,2,3, \#}$, Maya El Dor ${ }^{1,2,3}$, Firas Kobeissy ${ }^{4}$, \\ Fabrice Gouilleux ${ }^{1,2}$, Frédéric Mazurier ${ }^{1,2}$ and Kazem Zibara ${ }^{3,5, *}$
}

\author{
${ }^{1}$ Université de Tours, EA7501 GICC, Tours, France; ${ }^{2}$ CNRS ERL7001 LNOx, Tours, France; ${ }^{3}$ PRASE, Leba- \\ nese University, Beirut, Lebanon; ${ }^{4}$ Department of Biochemistry and Molecular Genetics, Faculty of Medi- \\ cine, American University of Beirut, Beirut, Lebanon; ${ }^{5}$ Biology Department, Faculty of Sciences-I, Lebanese \\ University, Beirut, Lebanon
}

\begin{abstract}
Drug repurposing has lately received increasing interest in several diseases especially in cancers, due to its advantages in facilitating the development of new therapeutic strategies, by adopting a cost-friendly approach and avoiding the strict Food and Drug Administration (FDA) regulations. Acriflavine (ACF) is an FDA approved molecule that has been extensively studied since 1912 with antiseptic, trypanocidal, anti-viral, anti-bacterial and anti-cancer effects. ACF has been shown to block the growth of solid and hematopoietic tumor cells. Indeed, ACF acts as an inhibitor of various proteins, including DNA-dependent protein kinases C (DNA-PKcs), topoisomerase I and II, hypoxia-inducible factor $1 \alpha$ (HIF-1 $\alpha$ ), in addition to its recent discovery as an inhibitor of the signal transducer and activator of transcription (STAT). Chronic myeloid leukemia (CML) is a clonal myeloproliferative disorder characterized by the expression of the constitutively active tyrosine kinase BCR-ABL. This protein allows the activation of several signaling pathways known for their role in cell proliferation and survival, such as the JAK/STAT pathway. CML therapy, based on tyrosine kinase inhibitors (TKIs), such as imatinib (IM), is highly effective. However, $15 \%$ of patients are refractory to IM, where in some cases, $20-30 \%$ of patients become resistant. Thus, we suggest the repurposing of ACF in CML after IM failure or in combination with IM to improve the anti-tumor effects of IM. In this review, we present the different pharmacological properties of ACF along with its anti-leukemic effects in the hope of its repurposing in CML therapy.
\end{abstract}

Keywords: Acriflavine, ACF, drug repurposing, chronic myeloid leukemia, leukemia, anti-tumoral, anti-leukemic.

\section{INTRODUCTION}

Drug repurposing, also known as "drug repositioning" or "drug reprofiling", has been lately receiving increased interest as a new therapeutic strategy for several diseases [1]. This strategy focuses on finding new possible therapeutic effects of a drug that already exists and which has been shown to establish good safety and pharmacokinetic profiles [2]. While drug research and development $(\mathrm{R} \& \mathrm{D})$ represents a long process with

*Address for correspondence to this author at the Department of Biology, Faculty of Sciences, Lebanese University, Beirut, Lebanon; Tel./Fax: +961-5-461496, +961-70-939994;

E-mail: kzibara@ul.edu.lb

${ }^{\#}$ These authors have contributed equally to the manuscript. high costs and complexity, drug repurposing has demonstrated many advantages facilitating the development of new therapeutic strategies in several diseases. Specifically, using available drugs as new anti-cancer agents has become popular [3]. For instance, retinoic acid or tretinoin was first introduced as a topical treatment for acne Vulgaris [4]. It was later largely described as an anti-leukemic agent for patients with acute promyelocytic leukemia (APL) who have previously relapsed from chemotherapy. In fact, the use of this repositioned drug has improved the survival of APL patients to more than $90 \%$ [5].

Drug repurposing could be an important therapeutic strategy for chronic myeloid leukemia (CML) treat- 
ment, where a previously used antiseptic agent, Acriflavine (ACF), has been reported to have beneficial effects. Hence, the aim of this review is to present ACF as a new repositioned drug, by providing an overview of its different uses and pharmacological properties, along with its new reported anti-leukemic effects in the hope of its repurposing in CML therapy.

\section{DRUG REPOSITIONING APPROACHES AND RESOURCES}

Since 1995, productivity of drug development has been decreased, despite the substantial increase of investments in pharmaceutical research and development $[6,7]$. Although the development of a new drug requires between 13 to 15 years, the average success rate of developing a new molecule is $\sim 2 \%$ only [8]. Thus, therapeutic innovation has become more challenging, and hence a new strategy for drug discovery is urgently needed.

To overcome the challenges of traditional de novo drug design, new approaches for drug discovery have been developed. With the highly evolving computational methods, in silico drug design has been widely applied in pharmaceutical drug discovery and optimization [9]. Such methods are defined by the creation of computational models or simulations of the therapeutic target that can be used to make predictions or to test the proposed hypothesis [10]. This approach presented a highly efficient, cost-friendly approach that required less time and allowed the parallel evaluation of a large number of drugs against one target, at the same time. Despite the promising results presented by the in silico drug design approach, challenges include the need to develop more complex computational technology as well as the high rate of false-positive results obtained during the experimental process [11].

Thereafter, drug repurposing has been introduced as a new approach for drug development, which will be our main focus in this review. In fact, the notion of 'old drugs for new uses' is a highly efficient, low-cost and riskless novel method to find new indications for existing drugs [12]. This strategy removes the steps of molecular origination, in vivo and in vitro screening, chemical optimization, pharmacokinetics, toxicology and possibly phase I clinical trials [13]. Lately, it has been widely used because of the simplicity of the drug approval procedure. Indeed, while only $10 \%$ of new drug applications gain FDA-approval, amongst the repositioned drugs, 30\% gain the approval [14]. Drug repurposing cost is estimated at an average of 20-100 million dollars $[13,15]$, a fraction of the average cost for de novo drug development. Moreover, it requires only 6.5 years of development $[12,16]$, thus offering a great opportunity to develop drugs with lower investments and shorter time. In addition, drug repurposing involving the use of generic therapies already approved by the FDA can offer a better risk-versus-reward tradeoff as compared with traditional drug development methods [17]. This is because repositioned drugs have already passed all clinical tests in the first three phases and their safety has been confirmed [18]. Historically, most of the repositioned drug candidates (e.g. sulfonamide, sildenafil, minoxidil, aspirin, valproic acid) have been discovered from serendipitous observations or from unorganized discovery processes such as offtarget adverse effects $[19,20]$. Thereafter, the detection of novel drug-disease relationships has been more organized and it is now possible due to the development of three kinds of approaches: computational, biological, and mixed [12].

Computational approaches have much lower costs and fewer barriers when compared to biological approaches. These approaches are based on the belief that similarity and shared properties between biological entities can help to identify their new mechanisms of action [6]. Computational drug repositioning methods include drug combination prediction, electronic health records (EHR), genome sequencing, structure-based repositioning, off-targeting data, protein abundance, protein-protein interactions (PPI), protein-small molecules interactions, pathways based repositioning, gene expression, and network-based repositioning $[6,12,21$ 23]. These computational approaches have been rapidly developed and improved due to the availability of a vast amount of experimental data covering various diseases that led to establishing massive databases from chemical, medical, pharmacological and biological fields. More than 80 databases or resources are currently used for designing drug repositioning approaches [12]. For instance, DrugBank is a unique pharmacological database that combines detailed drug data with comprehensive drug target information [24]. Proteomic databases such as MIPS are also important because they can provide high-quality PPI data from scientific literature [25]. In addition, numerous other databases could be used, such as ChemBank, OMIM, KEGG, PubMed, PDB, and others [12].

Experimental approaches include target-focused screening and phenotype screening approaches. The first is carried out in the context of a study evaluating a specific drug, while the second is a consequence of a screening study on a disease and its physiopathology. 
Phenotype screening includes all parts of the signaling pathways and cell behaviors; thus, it is considered more successful than the target-focused approach where the signaling pathways are not considered in the study [19]. Experimental methods may also include chemical genomics, chemical systems biology, serological markers, clinical side effects, genome-wide association studies (GWAS), network medicine and others [13].

The mixed approaches, which include both computational and experimental approaches, have been used in several studies $[12,21,26]$. In these mixed studies, preliminary outcomes of computational methods are confirmed by clinical tests and experiments.

Despite its efficiency, drug repurposing is still facing several challenges. In fact, it is highly dependent on the availability of information about the repurposed drug and the targeted molecule. The public access to certain types of data, such as clinical trials, is still limited despite the advanced open-source model of sharing information in the scientific community [18]. The different challenges and opportunities of traditional, in silico and repurposing drug development approaches, are presented in Table $\mathbf{1}$.

\section{ACRIFLAVINE}

Acriflavine or ACF, a mixture of 3,6-diamino-10methylacridinium chloride (Trypaflavin) and 3,6diaminoacridine (Proflavine), is a byproduct of coal tar initially developed in 1912 by the German medical research worker Paul Ehrlich and his assistant Benda [27]. ACF is an acridine derivative and it is considered as an attractive compound in medicine, science and industry [28]. It has first been introduced as an antiseptic during the First World War and used extensively to kill the parasites that cause sleeping sickness [29, 30]. Besides its trypanocidal activity reported in 1912, antibacterial activity has been reported in the next year by Carl Browning, a student of Ehrlich [31]. Thus, ACF popularity increased by being one of the first antibacterial agents to be discovered and used, until it has been replaced by penicillin [31].

ACF has the form of odorless, reddish-brown powder used in dilute aqueous solutions primarily as topical antiseptics or given orally, mainly as a urinary antiseptic [32]. As a member of acridine's family, ACF possesses two characteristics that have led researchers to consider it as a potential pharmacophore: its structure that permits its entry into the nucleus, and the intense fluorescence of the agent [29]. The anti-microbial activity of ACF has always been attributed to the fact that it intercalates into nucleic acids, thereby inhibiting bacterial and viral replication. Due to this process, ACF has been an interesting subject for important chemical investigations that lead to a better understanding of its action [33]. The structure is characterized by the presence of a planar polycyclic system presenting three rings and two substituent groups (Fig. 1). The biological effect of ACF has been referred to the planarity of these aromatic structures $[34,35]$, which can bind to double-stranded DNA through intercalation, thereby inhibiting a number of enzymes and interfering with many crucial cellular functions. In addition, the strong fluorescence properties of this compound allowed its use as a chemiluminescent agent $[33,36]$. Its international nonproprietary name (INN) is Acriflavinium chloride, and it continues to be used to this day as a highly effective disinfectant [37]. It is approved by the FDA of the United States for human non-oncological uses topically for the healing of wounds [38].

\section{ANTI-INFECTIOUS EFFECT OF ACF}

The first clinical use of ACF as an anti-microbial agent occurred in 1917 [27]. Since 1919, the Council on Pharmacy and Chemistry, an advisory board created in 1905 by the American Medical Association, approved its use in therapy [30]. The trypanocidal activity has been reported by Ehrlich team, who found that ACF possesses some therapeutic roles in trypanosome infections (Human African trypanosomiasis also known as sleeping sickness); hence it has been called Trpaflavine $[30,39]$. In the same context, being a strong DNA intercalating agent, ACF exhibited wide potent activities against various groups of microorganisms including Gonorrhea, HIV1 and malaria parasites [40].

Gonorrhea, a sexually transmitted infection (STI) caused by the bacterium Neisseria gonorrhoeae [41], has been treated by ACF for several years before it has been replaced by more targeted antibiotics [42]. ACF has also shown to be effective as a genito-urinary antiseptic. It occupied the main place in the treatment adopted in the venereal clinic [43]. In the nineties, Mathé et al., decided to investigate the effect of ACF in the treatment of HIV1 infection, knowing that it inhibits the synthesis and functions of proviral DNA [44], which showed promising results [40]. In other studies, ACF has been revealed to inhibit the growth of the human malaria parasite Plasmodium falciparum in vitro and in vivo, and it has been proposed as a powerful therapeutic molecule against malaria, an infection often associated with drug-resistance, mainly to chloroquine [40]. Several other indications have been further dis- 
Table 1. Advantages and disadvantages of drug design approaches.

\begin{tabular}{|c|c|c|c|}
\hline Drug Design Approaches & Advantages & Disadvantages & References \\
\hline Traditional drug design & $\begin{array}{l}\text { - Established a very efficient approach } \\
\text { for drug development } \\
\text {-High specificity in targeted therapy } \\
\text {-Low rate of false positives during ex- } \\
\text { periments }\end{array}$ & $\begin{array}{l}\text {-Time and labor consuming } \\
\text {-Estimated time: } 13-15 \text { years } \\
\text {-High costs } \\
\text {-Estimated costs: } 2-3 \text { billion dollars } \\
\text {-High failure rate in clinical trials } \\
\text {-Strict FDA restrictions }\end{array}$ & $\begin{array}{l}\text { Wong et al. (2014) [8] } \\
\text { Grinnan et al. (2019) [13] }\end{array}$ \\
\hline In silico drug design & $\begin{array}{c}\text {-Cost and time-efficient approach } \\
\text {-Easy to evaluate large number of drugs } \\
\text { at once } \\
\text {-Alternative to animal use } \\
\text {-Highly predictive }\end{array}$ & $\begin{array}{l}\text {-Higher rate of false positives dur- } \\
\text { ing the experiments } \\
\text {-Complex, needs high computa- } \\
\text { tional technology }\end{array}$ & $\begin{array}{l}\text { Ekins et al. (2007) [10] } \\
\text { Shim et al. (2014) [11] }\end{array}$ \\
\hline Drug repurposing & $\begin{array}{c}\text {-Time and labor efficient } \\
\text {-Estimated time: } 6.5 \text { years } \\
\text {-Cost-efficient approach } \\
\text {-Estimated costs: } 20-100 \text { million dollars } \\
\text {-Bypass early stages of drug develop- } \\
\text { ment } \\
\text {-Faster approach to enter the advanced } \\
\text { phases of clinical trials } \\
\text {-Bypass FDA restrictions }\end{array}$ & $\begin{array}{l}\text {-Higher rate of false positives re- } \\
\text { lated to the observations } \\
\text {-Highly dependent on information's } \\
\text { availability } \\
\text {-Needs to develop efficient drug } \\
\text { repurposing approaches }\end{array}$ & $\begin{array}{c}\text { Grinnan et al. (2019) [13] } \\
\text { Pushpakom et al. (2018) } \\
{[15]} \\
\text { Talevi et al. }(2020)[18]\end{array}$ \\
\hline Proflavine & & $\mathrm{H}$ & $\mathrm{H}$ \\
\hline
\end{tabular}

Fig. (1). Chemical structure of Proflavine and Trypaflavine. ACF is a mixture of (A) Proflavine $\left(\mathrm{C}_{13} \mathrm{H}_{11} \mathrm{~N}_{3}\right.$, Molar Mass= $\left.209.25 \mathrm{~g} \cdot \mathrm{mol}^{-1}\right)$ and $(\mathbf{B})$ Trypaflavin $\left(\mathrm{C}_{14} \mathrm{H}_{14} \mathrm{ClN}_{3}\right.$. Molar Mass $\left.=259.74 \mathrm{~g} \cdot \mathrm{mol}^{-1}\right)$.

covered, including its use in 1930 to treat severe undulant fever and its complications [47]. Despite all of these trials, ACF is currently not approved for any of these indications and it has been out of use systemically for more than 60 years, probably, because we do not understand its exact mechanism of action [40]. The only approved indication has been reported by Maxwell Quackenbos, who found that ACF's main value was not its antiseptic properties, but its remarkable power to stimulate epithelial growth on healthy granulating surfaces. Thus, he recommended the use of ACF dressings and noticed that healing occurs with great rapidity [48]. ACF is still widely used for wound dressing by health professionals and remains a popular, topical antiseptic agent purchased over-the-counter [49].

Since 1959, ACF has grabbed the attention of scientists working in cancer research due to its versatile biological activities [50]. Subsequently, its anti-bacterial and anti-protozoal effects were neglected and recent research has been mainly focused on its anti-cancer effects.

\section{POTENTIAL ROLE OF ACF IN CANCER TREATMENT}

The first use of ACF on cancer cells was reported 60 years ago when ACF, administered intraperitoneally into mice, completely inhibited the proliferation of tumor cells without affecting normal tissues [51]. A recent study demonstrated that ACF inhibits osteosarcoma cell proliferation in a dose-dependent manner, causing both apoptosis and autophagy, which are associated with the decrease in BCL-2 expression, a prosurvival protein, and the increase of BAX levels, a proapoptotic protein [46]. ACF was also shown to target patient-derived cells with advanced ovarian carcinoma in a dose-dependent manner [52]. The same team showed that ACF efficiently targeted colorectal cancer 
cells as well [52]. Moreover, ACF treatment of mice with prostate cancer xenografts prevented tumor growth and vascularization [53]. This was also observed by Shay et al., who demonstrated that ACF limits tumor progression of established colitis-associated colon cancer (CAC) in immune-competent mice in a HIF-1 dependent manner [54]. Furthermore, a preclinical study introduced ACF in brain tumor rat models via biodegradable wafers, which showed improved survival, resulting in nearly $100 \%$ long term survival [38]. Recent studies show that ACF inhibits hypoxia-induced pathways in glioma-implanted rodents, which participate in creating a tumor-immunosuppressive microenvironment [55]. These reports have also shown that the systematic administration of ACF decreased tumor size during the first two weeks, showing the promising use of ACF in glioma therapy [55]. Interestingly, ACF increased the cytotoxic effect of 5-fluorouracil (5-FU) in colorectal cancer cell lines, suggesting the development of new chemotherapy regimens that administer ACF in 5-FU-resistant patients with advanced colorectal cancer [56]. The pretreatment of human perihilar cholangiocarcinoma cells (SK-ChA-1) with ACF enhanced photodynamic therapy (PDT) efficacy through the inhibition of HIF-1 and topoisomerases I and II [57]. This was also noticed in murine breast carcinoma 4T1bearing mice, where ACF efficiently enhanced the antitumor effect of sunitinib, a VEGF receptor tyrosine kinase inhibitor [58]. This combination significantly decreased VEGF and TGF- $\beta$ expression along with reduced tumor vasculature leading to intra-tumor necrosis and apoptosis, thus proposing the use of HIF-1 inhibitors with antiangiogenic therapy for cancer patients [58]. Moreover, Wong et al., demonstrated that ACF inhibited HIF-1-mediated invasion and metastasis in human breast carcinoma xenografted mice [59]. The anti-tumor effects of ACF have also been assessed in human hepatocellular carcinoma (HCC). Lee et al., revealed that ACF treated mice experienced a 4-fold decrease tumor growth compared to vehicle-treated mice, which could provide a new therapeutical approach to extend the survival rate of patients in advanced stages (Table 2) [60].

\section{HUMAN USES, DOSES, AND SAFETY}

ACF has repeatedly shown to be an efficient HIF-1 $\alpha$ inhibitor with anti-tumor effects along with its safe use in vivo, thus allowing its integration in clinical trials along with other conventional therapy for diseases other than cancer (Table 3). The first-ever published administration of ACF in patients, with promising results, was for the treatment of gonorrhea by daily irri- gations of the bladder [61]. ACF was also used later in 1930 to treat severe undulant fever and its complications. It was intravenously administered to 7 patients, and results showed that the course of undulant fever was shortened along with the prevention of the development of arthritis compared to untreated patients [47]. In addition, ACF was tested in Phase I-II clinical trials, which involved 10 volunteers with HIV infections (Patent ref. FR2711527A1). It was administered orally at increasing doses of 5 to $200 \mathrm{mg}$ per day for 4 weeks to 8 months. Clinical trials revealed that the treatment allowed a stabilization of the disease in 6 patients. Interestingly, ACF was highly effective in HIV patients who are resistant to conventional treatment by dropping the levels of P24 antigen, showing a decrease in viral proteins in the blood.

Dosages of ACF were 25 to $250 \mathrm{mg}$ per day of active ingredient orally administered. For parenteral administration, 5 to $50 \mathrm{mg}$ per day of the active ingredient is directed. Moreover, the oral administration of ACF in HIV-1 patients, in combination with AZTellipticin, as an antiviral agent for 5 months did not evolve major side effects, thus suggesting that it is suitable for use in clinical trials 59. This observation was also noted by the same group after the treatment of HIV patients with ACF for 18 months to 6 years 60 . The median lethal dose (LD50) of ACF in humans is unclear, but the LD50 of ACF in mice is $30 \mathrm{mg} / \mathrm{kg}$. $\mathrm{ACF}$ is also introduced in an ongoing Phase IV clinical trial engaging 284 patients with recurrent cystitis, a bacterial infection in the urinary tract, having $\geq 2$ episodes within the past 6 months (Clinical trials ref. NCT03379389). The study aims to assess the efficacy of different treatments, which include or not ACF.

\section{CML STILL NEEDS A NEW THERAPY}

CML is a clonal disease that affects hematopoietic stem cells (HSCs), resulting in the accumulation of malignant hematopoietic cells in the blood and bone marrow (BM) of patients. CML affects 0.6-1 person per 100000 each year, with an average age at diagnosis around $57-60$ years $[63,64]$.

This neoplasia is characterized by the presence of a chromosomal abnormality, caused by reciprocal translocation $\mathrm{t}(9 ; 22)(\mathrm{q} 34 ; \mathrm{q} 11)$, which results in the expression of the constitutively active tyrosine kinase BCRABL [65]. This chimeric protein is expressed in $95 \%$ of CML cases, and it is responsible for the activation of several cellular pathways that are implicated in the malignancy of CML. Therefore, CML therapy is currently based on tyrosine kinase inhibitors (TKIs); 3 genera- 
Table 2. Effect of ACF in cancers.

\begin{tabular}{|c|c|c|c|c|}
\hline Cancer & Material & Dose of ACF & Outcomes & References \\
\hline Breast Cancer & $\begin{array}{l}\text { - Human MDA-MB-231 } \\
\text { and MDA-MB-435 cells } \\
\text { - Implantation of breast } \\
\text { cancer cells into SCID } \\
\text { mice }\end{array}$ & $\begin{array}{c}\text { in vivo: daily } \\
\text { intraperitoneal } \\
\text { (i.p.) injections at } \\
4 \mathrm{mg} / \mathrm{kg}\end{array}$ & $\begin{array}{c}\text { - ACF blocked hypoxia-induced expression of LOX } \\
\text { and LOXL proteins, collagen cross-linking, CD } 11 \mathrm{~b}^{+} \\
\text {bone marrow-derived cell recruitment } \\
\text { - ACF blocks breast cancer metastasis in an orthotopic } \\
\text { breast cancer model }\end{array}$ & $\begin{array}{l}\text { Wong et al., } \\
(2012) \text { [59] }\end{array}$ \\
\hline $\begin{array}{c}\text { Hepatocellular } \\
\text { Carcinoma (HCC) }\end{array}$ & $\begin{array}{l}\text { - Mahlavu, SK-Hep1, } \\
\text { Hep3B, Huh-7, and } \\
\text { PLC/PRF/5 cell lines } \\
\text { - BALB/cAnN. CgFoxn- } \\
\text { 1 }^{\mathrm{nu}} / \mathrm{CrlNarl} \text { mice }\end{array}$ & \begin{tabular}{|}
-in vitro: $1,2,5 \&$ \\
$10 \mu \mathrm{M}$ \\
-in vivo $:$ daily i.p. \\
injections at 2 \\
$\mathrm{mg} / \mathrm{kg}$
\end{tabular} & $\begin{array}{l}\text { - in vitro: ACF suppresses HCC cell growth through } \\
\text { the caspase- } 3 \text { activation pathway } \\
\text { - in vivo: ACF decreased tumor growth to approxi- } \\
\text { mately } 500 \mathrm{~mm} 3 \text { compared to vehicle-treated mice }\end{array}$ & $\begin{array}{l}\text { Lee } \text { et al., } \\
(2014)[60]\end{array}$ \\
\hline $\begin{array}{l}\text { Ovarian carci- } \\
\text { noma }\end{array}$ & $\begin{array}{l}\text { Patient-derived tumor } \\
\text { cells (PDTC) }\end{array}$ & $\begin{array}{l}\text { in vitro: } 0.2,1 \text { and } \\
5 \mu \mathrm{M}\end{array}$ & $\begin{array}{l}\text { - ACF inhibited cell proliferation in a dose-dependent } \\
\text { manner }\end{array}$ & $\begin{array}{l}\text { Hassan et al., } \\
\text { (2011) [52] }\end{array}$ \\
\hline $\begin{array}{l}\text { Colorectal cancer } \\
\text { (CRC) }\end{array}$ & $\begin{array}{l}\text { - PDTC } \\
\text { - HCT116 colon cancer } \\
\text { spheroids }\end{array}$ & $\begin{array}{c}\text { in vitro: } 0.2,1 \text { and } \\
5 \mu \mathrm{M}\end{array}$ & $\begin{array}{l}\text { - ACF inhibited cell proliferation in a dose-dependent } \\
\text { manner in PDTC } \\
\text { - Treatment with } 5 \mu \mathrm{M} \text { of ACF reduced the spheroid } \\
\text { volume compared to unexposed control spheroids }\end{array}$ & $\begin{array}{l}\text { Hassan et al., } \\
\text { (2011) [52] }\end{array}$ \\
\hline $\begin{array}{l}\text { Colorectal cancer } \\
\quad(\text { CRC) }\end{array}$ & $\begin{array}{l}\text { SW480, HCT } 116 \text { and } \\
\text { LS174T cell lines }\end{array}$ & $\begin{array}{c}\text { in vitro: } 0.07,015 \\
0.31,0.62,1.25 \\
2.5 \& 5 \mu \mathrm{M}\end{array}$ & $\begin{array}{c}\text {-Pretreatment with ACF sensitized CRC cells 5-FU } \\
\text {-Simultaneous treatment with ACF and 5-FU did not } \\
\text { alter the resistance of CRC cells to } 5-\mathrm{FU} \\
\text { - ACF is a more potent agent than irinotecan for en- } \\
\text { hancing the antitumor activity of } 5-\mathrm{FU} \\
\text { - ACF did not alter the mRNA levels of either HIF - } 1 \alpha \\
\text { or topoisomerase } 2\end{array}$ & $\begin{array}{l}\text { Zargar et al., } \\
(2018)[56]\end{array}$ \\
\hline $\begin{array}{l}\text { Perihilar Cholan- } \\
\text { giocarcinomas }\end{array}$ & SK-ChA-1 cells & $\begin{array}{l}\text { in vitro: } 1,3 \& 5 \\
\mu \mathrm{M}\end{array}$ & $\begin{array}{l}\text { - ACF increases expression of VEGF, CD105, } \\
\text { CD31/Ki-67, and GLUT-1 } \\
\text { - ACF was translocated to the nucleus under hypoxic } \\
\text { conditions in SK-ChA-1 cells } \\
\text { - Pretreatment with ACF enhanced PDT efficacy via } \\
\text { inhibition of HIF-1 and topoisomerases I and II }\end{array}$ & $\begin{array}{l}\text { Weijer et al., } \\
\text { (2016) [57] }\end{array}$ \\
\hline Brain cancer & $\begin{array}{l}\text { - Cell lines: Human U87 } \\
\text { cell line, mouse GL261 } \\
\text { cell line, rodent F98 cell } \\
\text { line, 9L gliosarcoma } \\
\text { - Human primary brain } \\
\text { tumor stem cell neuro- } \\
\text { sphere lines, GB1A, and } \\
\text { primary brain tumor JHH } \\
1113 \text { stem cell line } \\
\text { - F344 rats }\end{array}$ & $\begin{array}{l}\text { in vivo: daily i.p. } \\
\text { injections at } 5 \\
\mathrm{mg} / \mathrm{kg}\end{array}$ & $\begin{array}{l}\text { - ACF induces cytotoxicity and promotes apoptosis in } \\
\text { brain cancer cell lines } \\
\text { - ACF reduces the expression PGK1, VEGF and HIF- } \\
1 \alpha \text { in vitro and in vivo } \\
\text { - ACF promotes } 100 \% \text { long term survival }\end{array}$ & $\begin{array}{l}\text { Mangraviti et } \\
\text { al., (2017) } \\
{[38]}\end{array}$ \\
\hline
\end{tabular}


Table 3. Administration of ACF in clinical trials.

\begin{tabular}{|c|c|c|c|c|c|}
\hline Disease & Trial & Study Title & Patient Population & Outcomes & References \\
\hline $\begin{array}{l}\text { Undu- } \\
\text { lant } \\
\text { Fever }\end{array}$ & --- & $\begin{array}{l}\text { The Results of The Use of Acri- } \\
\text { flavine Hydrochloride in The } \\
\text { Treatment of Undulant Fever }\end{array}$ & $\begin{array}{l}-\mathrm{N}=14 \text { patients } \\
- \text { Sex: All } \\
-20 \geq \text { Age } \leq 49\end{array}$ & $\begin{array}{c}\text { - Untreated patients suffered from } \\
\text { fever from } 9 \text { months until } 2 \text { years, } 2 \\
\text { patients died } \\
\text {-Fever was arrested in } 5 \text { treated pa- } \\
\text { tients within } 1 \text { month } \\
\text {-2 treated patients still had fever but at } \\
\text { a lower level compared to untreated }\end{array}$ & $\begin{array}{l}\text { Thurber D.S., } \\
\text { (1930) [47] }\end{array}$ \\
\hline HIV & Phase I & $\begin{array}{l}\text { AIDS therapy with two, three or } \\
\text { four agent combinations, ap- } \\
\text { plied in short sequences, differ- } \\
\text { ing from each other by drug } \\
\text { rotation. i. first of two parts: a } \\
\text { phase i trial equivalent, concern- } \\
\text { ing five virostatics: azt, ddi, } \\
\text { ddc, acriflavine and an ellip- } \\
\text { ticine analogue }\end{array}$ & $\begin{array}{l}-\mathrm{N}=10 \text { patients } \\
\text {-Duration of treat- } \\
\text { ment: } 5 \text { months }\end{array}$ & $\begin{array}{c}\text {-Decrease of viral load to undetectable } \\
\text { levels after four months } \\
\text {-No side effects }\end{array}$ & $\begin{array}{l}\text { Mathé et al., } \\
\text { (1996) [45] }\end{array}$ \\
\hline HIV & Phase II & $\begin{array}{l}\text { Data of pre-clinical and early } \\
\text { clinical trials of acriflavine } \\
\text { and hydroxy-methyl-ellipticine } \\
\text { reviewed, enriched by the expe- } \\
\text { rience of } \\
\text { their use for } 18 \text { months to } 6 \\
\text { years in combinations } \\
\text { with other HIV1 virostatics }\end{array}$ & $\begin{array}{l}-\mathrm{N}=15 \text { patients } \\
-26 \geq \text { Age } \leq 45 \\
\text {-Duration of treat- } \\
\text { ment: } 1-8 \text { months }\end{array}$ & $\begin{array}{l}\text { - A slight increase of transaminases in } \\
2 \text { patients } \\
\text {-Decreases of the p } 24 \text { antigens in } 3 \\
\text { patients } \\
\text { - Stabilization of p } 24 \text { antigen in } 2 \text { pa- } \\
\text { tients }\end{array}$ & $\begin{array}{l}\text { Mathé et al., } \\
\text { (1998) [62] }\end{array}$ \\
\hline HIV & $\begin{array}{l}\text { Phase I- } \\
\text { II }\end{array}$ & $\begin{array}{c}\text { Use of acriflavine as an anti- } \\
\text { HIV agent }\end{array}$ & $\begin{array}{l}\text {-N }=10 \text { patients } \\
\text {-Ratio male:female } \\
9: 1 \\
\text {-Av. age: } 35.8 \text { years } \\
\text {-Duration of treat- } \\
\text { ment: } 4 \text { weeks }-8 \\
\text { months }\end{array}$ & $\begin{array}{c}\text {-ACF stabilized the expression of P24 } \\
\text { antigen in } 6 \text { patients } \\
\text {-ACF was effective in resistant pa- } \\
\text { tients } \\
\text { - ACF and its derivatives, can be used } \\
\text { in the treatment of AIDS }\end{array}$ & $\begin{array}{c}\text { FR2711527A } \\
1\end{array}$ \\
\hline
\end{tabular}

tions of which were released. Imatinib Mesylate (IM), the first, was introduced in 2001 as a selective BCRABL inhibitor, which improved the estimated overall survival of CML patients to $89 \%$, among which $60 \%$ of IM-treated patients completed a cytogenetic response [66]. However, despite the success of IM, 15\% of patients were refractory to the treatment from the beginning, while $50 \%$ of patients relapsed after IM discontinuation, demonstrating that IM is not totally curative [67]. IM resistance is explained by de novo mutations deforming the IM binding region of BCR-ABL, or by alternative activation of signaling pathways implicated in CML malignancy [68]. In addition, the hypoxic BM microenvironment maintains residual leukemia stem cells (LSCs) survival and stem cell potential, favoring self-renewal of LSCs in CML. LSC potential and selfrenewal capacities are highly associated with CMLpatients relapse after TKIs treatment [69]. This encouraged the development of secondgeneration TKIs, in the hope of overcoming IM resistance. Indeed, Dasatinib and Nilotinib were introduced and FDA approved in 2006 and 2007, respectively [70, 71]. Later, a third generation TKI (Ponatinib) was released and approved in 2013 [72]. These last two generations are highly associated with several side effects, including cardiovascular diseases and heart failure [73]. Therefore, devel- 
oping a new therapeutic strategy for CML treatment appears of extreme importance, and targeted CML therapy could be supported by drug repurposing of a previously existing drug.

\section{ACF AS AN ANTI-LEUKEMIC AGENT}

The first-ever reported anti-leukemic effect of ACF dates back to 1997 by Kim et al., [74] who tested the cytotoxic effects of ACF in Yac-1 leukemic mouse cells. The authors showed that ACF caused morphological changes in these cells, which could represent energy depletion. In 2011, a study showed that ACF inhibited chronic lymphoblastic leukemia (CLL) cell survival and proliferation [52]. Our team recently demonstrated a cytotoxic effect of ACF on MV-4-11 cell line, a current model for acute myeloid leukemia (AML) cells [75]. This is also in agreement with a study by Sabolova et al., who showed that ACF induces a dose-dependent inhibition of proliferation of HL-60 AML cell line and L1210 mice leukemia cells [76]. Furthermore, ACF was described for its potential anti-leukemic activity in K-562 and KCL-22 CML cell lines, which is related to its inhibitory potential against HIF [77].

HIFs are transcription factors that play crucial roles in the progression of several cancers, including leukemia [78]. Indeed, several studies confirmed that HIF-1 is a critical factor in CML progression and plays an important role in chemoresistance [79]. Its oncogenic activity in CML could be explained by the hypoxic nature of the BM microenvironment, since low oxygen levels $(<7 \%)$ stabilize HIF-1 $\alpha$, which binds to HIF-1 $\beta$ and activates the transcription of a large number of genes regulating cell survival, proliferation, and angiogenesis [80]. In addition, resident LSCs in the hypoxic $\mathrm{BM}$ are associated with chemoresistant CML through the activation of HIFs [81]. The genetic knockout of HIF-1 $\alpha$ in CML murine models prevents CML development, by targeting LSC cell cycle progression and apoptosis [82]. In addition, chemical inhibitors of HIFs showed promising results in leukemia treatment. For instance, the HIF- $1 \alpha$-binding activity blocker "echinomycin" induced apoptosis in AML LSCs, resulting in a decreased leukemia burden, and prolonged mice survival [83]. On the other hand, high concentrations of Lascorbic acid (AA) have been shown to inhibit the expression of HIF-1 $\alpha$ and reduce tumor growth in CML [84]. Moreover, the treatment of APL cell lines with the HIF-1 $\alpha$ inhibitor EZN-2208 conferred antileukemic activity by affecting cell migration and clonogenicity. Furthermore, In vivo combination treat- ment of EZN-2208 with ATRA (all-trans retinoic acid) eradicated leukemia cells, and prolonged mice survival [85]. In U973 cell lines, treatment with YC-1 inhibited HIF-1 $\alpha$ expression and triggered leukemia cells via mitochondrial-dependent apoptosis [86]. On the other hand, in vivo administration of $\mathrm{YC}-1$ in murine models of leukemia reduced leukemia burden and enhanced the survival rate [87]. Finally, ACF was reported as a selective inhibitor of HIF-1 activity, by binding directly to the PAS-B subdomain of both HIF- $1 \alpha$ and HIF- $2 \alpha$ subunits, preventing their hetero-dimerization with HIF-1 $\beta$, thereby inhibiting HIF-1-DNA-binding and transcriptional activity [53]. Indeed, the inhibitory activity of ACF against HIF-1 has been reported to induce blockage of tumor growth and tumor vascularization $[53,88]$.

Based on this information, ACF has become an interesting potential therapeutic approach for leukemia treatment, specifically targeting CML therapy. In 2017, Cheloni et al., showed that ACF targets LSCs of CML in vitro, where it was able to suppress the stem cell potential in CML cell lines and primary cells at the hypoxic condition. This capacity of suppressing stem cell potential of CML LSCs was reported even after long incubation of CML cells in hypoxia, revealing the importance of ACF anti-leukemic activity. Indeed, LSCs in CML patients are already incubated and adapted to low oxygen levels at the time of drug administration, which is usually associated with chemoresistance [89, 90]. The authors further confirmed the anti-leukemic effects of $\mathrm{ACF}$ in vivo using BCR-ABL-induced CML mice models, where ACF was capable of blocking leukemia development and reducing CML LSCs maintenance. In addition, ACF was also able to reduce the overall CML burden by reducing the severe splenomegaly and the number of CML cells in the BM and blood circulation of CML mice models treated with ACF [77].

In a recent study, our team demonstrated that ACF affected the growth and survival of CML and AML cell lines by targeting the STAT5 and STAT3 signaling pathway, without affecting BCR-ABL expression (Fig. 2) [75]. In fact, STAT3 and STAT5 are two transcription factors that are aberrantly activated in CML models by the constitutive activation of BCR-ABL that phosphorylates STAT factors at their tyrosine residues, causing their excessive activation [91]. In addition, STAT3 and STAT5 aberrant activation via JAK phosphorylation has been reported to contribute to the TKIresistance in CML [92]. Furthermore, STAT5 activation has been associated with CML LSCs maintenance 




Fig. (2). Mechanism of action of ACF in CML. Canonical activation of STAT5 starts after binding of cytokines to their specific membrane receptors, inducing receptor dimerization, followed by tyrosine phosphorylation and activation of the receptorassociated tyrosine kinase JAK. In its turn, JAK mediates the tyrosine phosphorylation of STAT5 that dimerizes. The active STAT5 dimers are translocated to the nucleus, to bind with their target DNA sequences. In CML, the expression of the protooncogene BCR-ABL, leads to the constitutive activation of STAT5, directly by the tyrosine kinase activity of BCR-ABL. At the same time, the low oxygen levels in the bone marrow microenvironment stabilize the two hypoxia inducible factors HIF-1 $\alpha$ and HIF-1 $\beta$ leading to their dimerization. The active dimer HIF- $1 \alpha / \mathrm{HIF}-1 \beta$ is translocated to the nucleus to activate the transcription of its target genes. Both activation of STAT5 and HIF- $1 \alpha / \mathrm{HIF}-1 \beta$ are associated with transcription of genes essential for proliferation, survival and chemo-resistance of CML cells. ACF inhibits both HIF- $1 \alpha / \mathrm{HIF}-1 \beta$ dimerization by binding directly to HIF-1 $\alpha$, and STAT5 expression and phosphorylation, resulting in inhibition of transcription of oncogenes, therefore inducing apoptosis and cell cycle arrest. In addition, ACF intercalates directly in the DNA sequence causing genomic stress. $(A$ higher resolution / colour version of this figure is available in the electronic copy of the article).

[93]; thus STAT3/5 were considered as critical targets and the development of drugs inhibiting these transcription factors holds promise as a treatment for CML. The results of extensive research on STAT3/5 and their inhibitors are presented in an important monograph on STATs [94]. Several natural and synthetic molecules were identified as STAT inhibitors and tested in different cancers, including leukemia. In addition to that, several drugs were repurposed to be used as STAT inhibitors, Pimozide is one of them. This neuroleptic drug works by decreasing the activity of dopamine in the brain and it is approved to be used in Tourette syndrome [95]. Pimozide has later been identified in a cell screening assay as a STAT5 inhibitor that blocks CML cell growth $[96,97]$. It also showed a synergistic effect with IM and Nilotinib in eradicating CML cells, thus overcoming TKI resistance [97]. Thus, targeting both HIFs and STAT signaling by ACF might potentially eradicate CML LSCs, and hence, prevent CML patients relapse after TKI treatment. Therefore, ACF- induced downregulation of STAT5 expression/activity in CML, along with the upregulation of STAT3 phosphorylation, could potentially lead to the inhibition of CML cells' survival and proliferation[75]. For instance, the anticancer chemotherapeutic agent doxorubicin showed STAT3 activation through JAK kinase phosphoryla- 
tion, and was associated with growth inhibition in response to stress generation [98]. Moreover, we demonstrated that increased ACF doses induced DNA damage, associated with its DNA intercalating property, thus triggering apoptosis of CML cells. In line with these data, ACF was also reported as an inhibitor of topoisomerase I/II, which plays a crucial role in controlling DNA structure and DNA repair. Indeed, inhibitors of such proteins were reported as anti-cancer agents in several solid cancers and leukemia [52], thus, the ACF DNA-intercalating property is suggested to trigger apoptosis. Furthermore, activating the P $21^{\text {Waf1 }}$ protein, an important marker of cellular senescence, was reported at a low concentration of ACF, suggesting that ACF might also induce a senescent phenotype in CML cells. Finally, ACF showed positive effects in IM-resistant CML cells sensitization, suggesting that ACF might be a useful drug that could be used alone or in combination with IM in order to alleviate resistant cells [75]. In summary, ACF presents a promising therapeutic strategy against CML, by inhibiting both HIF-1 and STAT5 transcription factors, and by eradicating TKI-resistant leukemia cells. Different studies of ACF in leukemia are summarized in Table 4. Since ACF has proven to be safely used in humans, thus re- purposing ACF in CML therapy presents an interesting strategy that has to be further investigated.

\section{CHALLENGES AND OPPORTUNITIES OF THE THERAPEUTIC IMPLICATION OF ACF}

Unlike other drugs that inhibit HIF-1 activity indirectly, ACF has shown to bind directly to both HIF-1 $\alpha$ and HIF-2 $\beta[99,100]$. ACF has been administered to patients for targeting different malignancies without any major side effects $[38,47,62]$. In addition, the incorporation of $\mathrm{ACF}$, along with conventional therapy of various diseases showed that ACF increases the antitumor effects of the latter without affecting normal homeostasis [77]. Thus, these observations propose ACF as the lead compound for the development of drugs that are efficient in treating patients with diseases characterized by increased HIF- $1 \alpha$ or HIF- $2 \alpha$ levels that are essential for malignancy progression. However, the challenge lies in the validation of the specificity of ACF towards its targets, which should be further investigated in order to assure the absence of any off-target effects. Moreover, the implication of ACF in clinical trials has not been extensively applied. Thus, further studies should be involved in order to determine the exact doses of ACF that should be administered. An-

Table 4. The effect of ACF in leukemia.

\begin{tabular}{|c|c|c|c|c|}
\hline Leukemia & Material & Dose of ACF & Outcome & References \\
\hline T Cell Lymphoma & $\begin{array}{l}\text {-Yac-1 mouse } \\
\text { leukemia cells }\end{array}$ & $\begin{array}{l}\text { In vitro: various } \\
\text { concentrations of ACF }\end{array}$ & $\begin{array}{l}-\mathrm{IC}_{50} \text { value is } 2.11 \mu \mathrm{M} \text {; } \\
\text {-ACF leads to morphological changes in } \\
\text { Yac-1 cells, including bleb formations, } \\
\text { swelling and ballooning }\end{array}$ & $\begin{array}{l}\text { Kim et al., } \\
(1997)[74]\end{array}$ \\
\hline $\begin{array}{l}\text { Chronic Lymphocytic } \\
\text { Leukemia (CLL) }\end{array}$ & $\begin{array}{l}\text {-Patient-derived } \\
\text { tumor cells } \\
\text { (PDTC) }\end{array}$ & $\begin{array}{c}\text { In vitro: } 0.2,1 \text { and } 5 \\
\mu \mathrm{M}\end{array}$ & $\begin{array}{l}\text {-ACF inhibits cell proliferation in a dose- } \\
\text { dependent manner in PDTC }\end{array}$ & $\begin{array}{l}\text { Hassan et al., } \\
\text { (2011) [52] }\end{array}$ \\
\hline \multirow{2}{*}{$\begin{array}{l}\text { Acute Myeloid Leu- } \\
\text { kemia (AML) }\end{array}$} & $\begin{array}{l}-\mathrm{MV}-4-11 \text { cell } \\
\text { line }\end{array}$ & $\begin{array}{c}\text { In vitro: } 0.5,1,2,4,8 \\
\mu \mathrm{M}\end{array}$ & $\begin{array}{l}\text {-ACF downregulates STAT5 expression } \\
\text {-ACF exerts a cytotoxic effect on AML } \\
\text { cells }\end{array}$ & $\begin{array}{l}\text { Hallal et al., } \\
(2020)[75]\end{array}$ \\
\hline & $\begin{array}{l}\text {-HL-60 cell line } \\
\text {-L1210 cells }\end{array}$ & $\begin{array}{l}\text { In vitro: various } \\
\text { concentrations of } \mathrm{ACF}\end{array}$ & $\begin{array}{c}\text {-ACF has cytotoxic effect against HL-60 } \\
\text { cells with } \mathrm{IC}_{50} \text { value }=4.94 \mu \mathrm{M} \\
-\mathrm{IC}_{50} \text { value }=5.99 \mu \mathrm{M} \text { for } \mathrm{L} 1210 \text { cells }\end{array}$ & $\begin{array}{l}\text { Sabolova et al., } \\
\quad(2020)[76]\end{array}$ \\
\hline $\begin{array}{l}\text { Chronic Myeloid } \\
\text { Leukemia (CML) }\end{array}$ & $\begin{array}{l}-\mathrm{K}-562 \text { cell line } \\
-\mathrm{KCL}-22 \text { cell line }\end{array}$ & $\begin{array}{c}\text { In vitro: } \\
\qquad .5,1,2,4,8 \\
\mu \mathrm{M}\end{array}$ & $\begin{array}{l}\text {-ACF downregulates STAT5 expression } \\
\text {-ACF induces apoptosis in a dose- } \\
\text { dependent manner } \\
\text {-ACF suppresses the resistance of CML } \\
\text { cells to Imatinib }\end{array}$ & $\begin{array}{l}\text { Hallal et al., } \\
(2020)[75]\end{array}$ \\
\hline
\end{tabular}


other challenge includes the investigation of ADMET (absorption, distribution, metabolism, excretion, and toxicity) of ACF in order to better incorporate it in clinical trials. Regardless of the extensive work required for the study of ACF, its anti-tumor effects have shown to be efficient in different cancers previously mentioned, thus showing promising results in not only eradicating CML, but also in other malignancies and cancer types [52, 54, 75]

\section{CONCLUSION}

CML patients are still facing a lack of efficacy with available TKIs in around $15 \%$ of cases. Besides, resistance mechanisms are not yet fully understood. Thus, developing a new treatment for these refractory cases remains considerably challenging. Drug repurposing has recently emerged as a promising tool for novel drug discovery in a wide range of cancers. It is relatively rapid and cost-effective, with minimal risk on patients. We have proved a cytotoxic effect of ACF on CML cells, thus suggesting it as a promising candidate for drug repurposing in CML patients. Indeed, ACF has already demonstrated to be safely administered to patients, without showing major side effects. However, chemical modifications should be considered in order to have a better bioavailability of the drug. Overall, we suggest the use of ACF in CML therapy alone, or in combination with other conventional drugs for the treatment of CML resistant to TKIs.

\section{LIST OF ABBREVIATIONS}

$\begin{array}{ll}\text { 5-FU } & \text { 5-fluorouracil } \\ \text { ACF } & \text { Acriflavine } \\ \text { ADMET }= & \text { Absorption, distribution, metabolism, } \\ & \text { excretion, and toxicity } \\ \text { AIDS } & \text { Acquired immunodeficiency syndrome } \\ \text { AML } & =\text { Acute myeloid leukemia } \\ \text { APL } & =\text { Acute promyeloctic leukemia } \\ \text { ATRA } & \text { All-trans retinoic acid } \\ \text { AZT } & =\text { Azidothymidine } \\ \text { BAX } & =\text { Bcl-2-associated } \\ \text { Bcl-2 } & =\text { B-cell lymphoma } 2 \text { protein } \\ \text { BCR-ABL }= & \text { Breakpoint cluster region }- \text { Abelson } \\ \text { BM } & =\text { Bone marrow } \\ \text { CAC } & =\text { Associated colon cancer }\end{array}$

CLI

CLL

$=$ Chronic lymphoblastic leukemia

CML

$=$ Chronic myeloid leukemia

$\mathrm{CRC}$

$=$ Colorectal cancer

EHR

$=$ Electronic health records

FDA

$=$ Food and drug administration

GWAS $=$ Genome wide association studies

HCC = Human hepatocellular carcinoma

HIF $\quad=$ Hypoxia inducible factor

HIV = Human immunodeficiency virus

HSC = Hematopoietic stem cells

IM = Imatinib

INN $=$ International nonproprietary name

IP $=$ Intraperitoneal

JAK = Janus kinase

LSC = Leukemia stem cells

PAS-B = Per-Arnt-Sim B subdomain

PDT = Photodynamic therapy

PDTC $=$ Patient derived tumor cells

PGK1 = Phosphoglycerate Kinase 1

PPI = Protein-protein interactions

SCID mice $=$ Severe combined immunodeficient mice

STAT = Signal transducer and activator of transcription

STI = Sexually transmitted infection

TGF- $\beta=$ Transforming growth factor beta

TKI $=$ Tyrosine kinase inhibitor

VEGF = Vascular endothelial growth factor

\section{CONSENT FOR PUBLICATION}

Not applicable.

\section{FUNDING}

None.

\section{CONFLICT OF INTEREST}

The authors declare no conflict of interest, financial or otherwise.

\section{ACKNOWLEDGEMENTS}

Declared none. 


\section{REFERENCES}

[1] Langedijk, J.; Mantel-Teeuwisse, A. K.; Slijkerman, D. S.; Schutjens, M. H. D. B. Drug Repositioning and Repurposing: Terminology and Definitions in Literature Drug Discovery Today, 2015, 1027-1034.

[2] review of network-based approaches to drug repositioning | Briefings in Bioinformatics | Oxford Academic https://academic.oup.com/bib/articleabstract/19/5/878/3056737?redirectedFrom=fulltext

[3] Sleire, L.; FA,rde-Tislevoll, H. E.; Netland, I. A.; Leiss, L.; Skeie, B. S.; Enger, P. A . Drug Repurposing in Cancer Pharmacological Research, 2017, , 74-91.

[4] Rathi, S.K. Acne vulgaris treatment : the current scenario. Indian J. Dermatol., 2011, 56(1), 7-13. http://dx.doi.org/10.4103/0019-5154.77543 PMID: 21572783

[5] Damery, E.; Solimando, D. A.; Waddell, J. A. Arsenic Trioxide and Tretinoin (AsO/ATRA) for Acute Promyelocytic Leukemia (APL) Hospital Pharmacy, 2016, , 628-632.

[6] Yeu, Y.; Yoon, Y.; Park, S. Protein localization vector propagation: a method for improving the accuracy of drug repositioning. Mol. Biosyst., 2015, 11(7), 2096-2102. http://dx.doi.org/10.1039/C5MB00306G PMID: 25998487

[7] Pammolli, F.; Magazzini, L.; Riccaboni, M. The productivity crisis in pharmaceutical R\&D. Nat. Rev. Drug Discov., 2011, 10(6), 428-438. http://dx.doi.org/10.1038/nrd3405 PMID: 21629293

[8] Wong, H.-H.; Jessup, A.; Sertkaya, A.; Birkenbach, A.; Berlind, A.; Eyraud, J. EXAMINATION OF CLINICAL TRIAL COSTS AND BARRIERS FOR DRUG DEVELOPMENT FINAL 2014.

[9] Cha, Y.; Erez, T.; Reynolds, I. J.; Kumar, D.; Ross, J.; Koytiger, G.; Kusko, R.; Zeskind, B.; Risso, S.; Kagan, E. Drug Repurposing from the Perspective of Pharmaceutical Companies British Journal of Pharmacology, 2018, , 168180.

[10] Ekins, S. Mestres, J.; Testa, B. In Silico Pharmacology for Drug Discovery: Methods for Virtual Ligand Screening and Profiling. British Journal of Pharmacology; WileyBlackwell, 2007, pp. 9-20.

[11] Shim, J. S.; Liu, J. O. Recent Advances in Drug Repositioning for the Discovery of New Anticancer Drugs International Journal of Biological Sciences, 2014, , 654-663.

[12] Xue, H.; Li, J.; Xie, H.; Wang, Y. Review of drug repositioning approaches and resources. Int. J. Biol. Sci., 2018, 14(10), 1232-1244.

[13] Grinnan, D.; Trankle, C.; Andruska, A.; Bloom, B.; Spiekerkoetter, E. Drug repositioning in pulmonary arterial hypertension: challenges and opportunities. Pulm. Circ., 2019, 9(1)

[14] Hernandez, J. J.; Pryszlak, M.; Smith, L.; Yanchus, C.; Kurji, N.; Shahani, V. M.; Molinski, S. V. Giving Drugs a Second Chance: Overcoming Regulatory and Financial Hurdles in Repurposing Approved Drugs as Cancer Therapeutics Frontiers in Oncology, 2017,

[15] Pushpakom, S.; Iorio, F.; Eyers, P. A.; Escott, K. J.; Hopper, S.; Wells, A.; Doig, A.; Guilliams, T.; Latimer, J.; McNamee, C. Drug Repurposing: Progress, Challenges and Recommendations Nature Reviews Drug Discovery, 2018, , 41-58.

[16] Yaseen, S.; Akram, S. DRUG REPOSITIONING, AN APPROACH FOR IDENTIFICATION OF NEW THERAPEUTICS. J. Nat. Appl. Sci. Pakistan, 2019, 1(2), 20192192.
[17] Ashburn, T.T.; Thor, K.B. Drug Repositioning: Identifying and Developing New Uses for Existing Drugs. Nature Reviews Drug Discovery; Nature Publishing Group, 2004, pp. 673-683.

[18] Talevi, A.; Bellera, C.L. Challenges and opportunities with drug repurposing: finding strategies to find alternative uses of therapeutics. Expert Opin. Drug Discov., 2020, 15(4), 397-401.

http://dx.doi.org/10.1080/17460441.2020.1704729 PMID: 31847616

[19] Dehpour, A.R. Drug Repositioning. RE:view, 2018, 1, 2े?

[20] Quianzon, C.C.L.; Cheikh, I.E. History of current noninsulin medications for diabetes mellitus. J. Community Hosp. Intern. Med. Perspect., 2012, 2(3), 19081. http://dx.doi.org/10.3402/jchimp.v2i3.19081 PMID: 23882374

[21] Amelio, I.; Gostev, M.; Knight, R.A.; Willis, A.E.; Melino, G.; Antonov, A.V. DRUGSURV: a resource for repositioning of approved and experimental drugs in oncology based on patient survival information. Cell Death Dis., 2014, $5(2) \mathrm{e} 1051$

http://dx.doi.org/10.1038/cddis.2014.9 PMID: 24503543

[22] Musa, A.; Ghoraie, L.S.; Zhang, S-D.; Glazko, G.; YliHarja, O.; Dehmer, M.; Haibe-Kains, B.; Emmert-Streib, F. A review of connectivity map and computational approaches in pharmacogenomics. Brief. Bioinform., 2018, 19(3), 506523.

http://dx.doi.org/10.1093/BIB PMID: 28069634

[23] Lotfi Shahreza, M.; Ghadiri, N.; Mousavi, S.R.; Varshosaz, J.; Green, J.R. A review of network-based approaches to drug repositioning. Brief. Bioinform., 2018, 19(5), 878-892. http://dx.doi.org/10.1093/bib/bbx017 PMID: 28334136

[24] Wishart, D.S.; Knox, C.; Guo, A.C.; Shrivastava, S.; Hassanali, M.; Stothard, P.; Chang, Z.; Woolsey, J. DrugBank: a comprehensive resource for in silico drug discovery and exploration. Nucleic Acids Res., 2006, 34(Database issue), D668-D672. http://dx.doi.org/10.1093/nar/gkj067 PMID: 16381955

[25] Mewes, H.W.; Hani, J.; Pfeiffer, F.; Frishman, D. MIPS: a database for protein sequences and complete genomes. $\mathrm{Nu}$ cleic Acids Res., 1998, 26(1), 33-37.

http://dx.doi.org/10.1093/nar/26.1.33 PMID: 9399795

[26] Ai, N.; Wood, R.D.; Welsh, W.J. Identification of Nitazoxanide as a Group I Metabotropic Glutamate Receptor Negative Modulator for the Treatment of Neuropathic Pain: An In Silico Drug Repositioning Study. Pharm. Res., 2015, 32(8), 2798-2807.

http://dx.doi.org/10.1007/s11095-015-1665-7 PMID: 25762088

[27] Wainwright, M. Acridine-a neglected antibacterial chromophore. J. Antimicrob. Chemother., 2001, 47(1), 1-13. http://dx.doi.org/10.1093/jac/47.1.1 PMID: 11152426

[28] Nasim, A.; Brychcy, T. Genetic Effects of Acridine Compounds Mutation Research/Reviews in Genetic Toxicology, 1979, , 261-288.

[29] Kumar, R.; Kaur, M.; Kumari, M. Acridine: a versatile heterocyclic nucleus. Acta Pol. Pharm., 2012, 69(1), 3-9. PMID: 22574501

[30] Hydrochloride, A.; Base, A. J. Am. Med. Assoc., 1929, 93(9), 695-696.

http://dx.doi.org/10.1001/jama.1929.02710090035014

[31] Relationships between Antiseptic Action and Chemical Constitution with Special Reference to Compounds of the Pyridine, Quinoline, Acridine and Phenazine Series Proc. R. Soc. 
London. Ser. B, Contain. Pap. a Biol. Character, 1922, 93(653), 329-366.

[32] Assinder, E.W. ACRIFLAVINE AS A URINARY ANTISEPTIC. Lancet, 1936, 227(5867), 304-305.

http://dx.doi.org/10.1016/S0140-6736(00)56423-X

[33] Kristian, P. Acridine Isothiocyanates: Chemistry and Biology; LAP LAMBERT Academic Publishing, 2014.

[34] Arnab Mukherjee, W.D.S. Proflavine - an Overview. $A d v$. Protein Chem. Struct. Biol., 2013.

[35] Ko 3/4urkovA 2 , M.; SabolovA D.; Kristian, P. A review on acridinylthioureas and its derivatives: biological and cytotoxic activity. J. Appl. Toxicol., 2017, 37(10), 11321139.

http://dx.doi.org/10.1002/jat.3464 PMID: 28370171

[36] Je 3/4ek, J.; HlavA 2 ?ek, J.; ebestA-k, J. Biomedical Applications of Acridines, 2017, 72

http://dx.doi.org/10.1007/978-3-319-63953-6

[37] Albert, A. The Acridines: Their Preparation, Physical, Chemical, and Biological Properties and Uses, 2nd ed; Edward Arnold: London, 1966.

[38] Mangraviti, A.; Raghavan, T.; Volpin, F.; Skuli, N.; Gullotti, D.; Zhou, J.; Asnaghi, L.; Sankey, E.; Liu, A.; Wang, Y. HIF-1I - Targeting Acriflavine Provides Long Term Survival and Radiological Tumor Response in Brain Cancer Therapy. Sci. Rep., 2017, 7(1), 1-13.

http://dx.doi.org/10.1038/s41598-017-14990-w PMID: 28127051

[39] Collins, G.W.; Stasiak, A. Comparative Chemical Examination of Different Brands of Acriflavine Hydrochloride (Acriflavine) and Acriflavine Base $(2$ ?oNeutral ?? Acriflavine). J. Am. Pharm. Assoc., 1929, 18(7), 659-669. http://dx.doi.org/10.1002/jps.3080180703

[40] Dana, S.; Prusty, D.; Dhayal, D.; Gupta, M.K.; Dar, A.; Sen, S.; Mukhopadhyay, P.; Adak, T.; Dhar, S.K. Potent antimalarial activity of acriflavine in vitro and in vivo. ACS Chem. Biol., 2014, 9(10), 2366-2373.

http://dx.doi.org/10.1021/cb500476q PMID: 25089658

[41] Vicentini, C.B.; Manfredini, S.; Maritati, M.; Di Nuzzo, M.; Contini, C. Gonorrhea, a current disease with ancient roots: from the remedies of the past to future perspectives. Infez. Med., 2019, 27(2), 212-221.

PMID: 31205048

[42] Acriflavine | antiseptic and dye | Britannica https://www.britannica.com/science/acriflavine

[43] Watson, D. The Treatment of Gonorrhoea with Acriflavine. BMJ, 1919, 1(3045), 571-572.

http://dx.doi.org/10.1136/bmj.1.3045.571 PMID: 20769469

[44] MathA(c), G.; Huppert, J.; Chenu, E.; Bourut, C. Amino acridines action on Friend 2 (tm)s retrovirus in relation to their molecular ionization. Biomed. Pharmacother., 1989, 43(4), 235-236.

http://dx.doi.org/10.1016/0753-3322(89)90002-4 PMID: 2790144

[45] MathA(c), G.; Pontiggia, P.; Orbach-Arbouys, S.; Triana, K.; Ambetima, N.; Morette, C.; Hallard, M.; Blanquet, D. AIDS therapy with two, three or four agent combinations, applied in short sequences, differing from each other by drug rotation. I. First of two parts: a phase I trial equivalent, concerning five virostatics: AZT, ddI, ddC, acriflavine and an ellipticine analogue. Biomed. Pharmacother., 1996, 50(5), 220-227.

http://dx.doi.org/10.1016/0753-3322(96)87662-1 PMID: 8949403
[46] Fan, J.; Yang, X.; Bi, Z. Acriflavine suppresses the growth of human osteosarcoma cells through apoptosis and autophagy. Tumour Biol., 2014, 35(10), 9571-9576.

http://dx.doi.org/10.1007/s13277-014-2156-x PMID: 24961347

[47] Thurber, D.S. THE RESULTS OF THE USE OF ACRIFLAVINE HYDROCHLORIDE IN THE TREATMENT OF UNDUlANT FEVER. Can. Med. Assoc. J., 1930, 23(5), 665-668.

PMID: 20318053

[48] Quackenbos, M. The Use of Acriflavine Journal of the American Medical Association, 1919,

[49] Leelavathi, M.; Le, Y.; Tohid, H.; Hasliza, A. Contact dermatitis presenting as non-healing wound: case report. Asia Pac. Fam. Med., 2011, 10(1), 6. http://dx.doi.org/10.1186/1447-056X-10-6 PMID: 21575147

[50] GOLDIE H. WALKER M, GRAHAM T, W. F. Topical Effect of Acriflavine Com... Preview \& Related Info | Mendeley. Inst., 1959, 23, 841-855.

[51] Topical Effect of Acriflavine Compounds on Growth and Spread of Malignant Cells https://pubmed.ncbi.nlm.nih.gov/13850654/?dopt=Abstra ct

[52] Hassan, S.; Laryea, D.; Mahteme, H.; Felth, J.; FryknAs, M.; Fayad, W.; Linder, S.; Rickardson, L.; Gullbo, J.; Graf, W.; PA hlman, L.; Glimelius, B.; Larsson, R.; Nygren, P. Novel activity of acriflavine against colorectal cancer tumor cells. Cancer Sci., 2011, 102(12), 2206-2213. http://dx.doi.org/10.1111/j.1349-7006.2011.02097.x PMID: 21910782

[53] Lee, K.; Zhang, H.; Qian, D.Z.; Rey, S.; Liu, J.O.; Semenza, G.L. Acriflavine inhibits HIF-1 dimerization, tumor growth, and vascularization. Proc. Natl. Acad. Sci. USA, 2009, 106(42), 17910-17915.

http://dx.doi.org/10.1073/pnas.0909353106 PMID: 19805192

[54] Shay, J.E.S.; Imtiyaz, H.Z.; Sivanand, S.; Durham, A.C.; Skuli, N.; Hsu, S.; Mucaj, V.; Eisinger-Mathason, T.S.; Krock, B.L.; Giannoukos, D.N.; Simon, M.C. Inhibition of hypoxia-inducible factors limits tumor progression in a mouse model of colorectal cancer. Carcinogenesis, 2014, 35(5), 1067-1077.

http://dx.doi.org/10.1093/carcin/bgu004 PMID: 24408928

[55] Guo, X.; Xue, H.; Shao, Q.; Wang, J.; Guo, X.; Chen, X.; Zhang, J.; Xu, S.; Li, T.; Zhang, P.; Gao, X.; Qiu, W.; Liu, Q.; Li, G. Hypoxia promotes glioma-associated macrophage infiltration via periostin and subsequent M2 polarization by upregulating TGF-beta and M-CSFR. Oncotarget, 2016, 7(49), 80521-80542.

http://dx.doi.org/10.18632/oncotarget.11825 PMID: 27602954

[56] Zargar, P.; Ghani, E.; Mashayekhi, F.J.; Ramezani, A.; Eftekhar, E. Acriflavine enhances the antitumor activity of the chemotherapeutic drug 5-fluorouracil in colorectal cancer cells. Oncol. Lett., 2018, 15(6), 10084-10090. http://dx.doi.org/10.3892/ol.2018.8569 PMID: 29928378

[57] Weijer, R.; Broekgaarden, M.; Krekorian, M.; Alles, L.K.; van Wijk, A.C.; Mackaaij, C.; Verheij, J.; van der Wal, A.C.; van Gulik, T.M.; Storm, G.; Heger, M. Inhibition of hypoxia inducible factor 1 and topoisomerase with acriflavine sensitizes perihilar cholangiocarcinomas to photodynamic therapy. Oncotarget, 2016, 7(3), 3341-3356. http://dx.doi.org/10.18632/oncotarget.6490 PMID: 26657503 
[58] Yin, T.; He, S.; Shen, G.; Wang, Y. HIF-1 Dimerization Inhibitor Acriflavine Enhances Antitumor Activity of Sunitinib in Breast Cancer Model. Oncol. Res., 2014, 22(3), 139145.

http://dx.doi.org/10.3727/096504014X13983417587366 PMID: 26168132

[59] Wong, C.C.L.; Zhang, H.; Gilkes, D.M.; Chen, J.; Wei, H.; Chaturvedi, P.; Hubbi, M.E.; Semenza, G.L. Inhibitors of hypoxia-inducible factor 1 block breast cancer metastatic niche formation and lung metastasis. J. Mol. Med. (Berl.), 2012, 90(7), 803-815.

http://dx.doi.org/10.1007/s00109-011-0855-y PMID: 22231744

[60] Lee, C.J.; Yue, C.H.; Lin, Y.Y.; Wu, J.C.; Liu, J.Y. Antitumor activity of acriflavine in human hepatocellular carcinoma cells. Anticancer Res., 2014, 34(7), 3549-3556. PMID: 24982368

[61] Davis, E.G.; Harrell, B.E. Acriflavine in the Treatment of Gonorrhoea ?"An Experimental and Clinical Study. J. Urol., 1918, 2(4), 257-276. http://dx.doi.org/10.1016/S0022-5347(17)74204-8

[62] MathA(c), G.; Triana, K.; Pontiggia, P.; Blanquet, D.; Hallard, M.; Morette, C. Data of pre-clinical and early clinical trials of acriflavine and hydroxy-methyl-ellipticine reviewed, enriched by the experience of their use for 18 months to 6 years in combinations with other HIV1 virostatics. Biomed. Pharmacother., 1998, 52(9), 391-396.

http://dx.doi.org/10.1016/S0753-3322(99)80007-9 PMID: 9856286

[63] HAglund, M.; Sandin, F.; Simonsson, B. Epidemiology of Chronic Myeloid Leukaemia: An Update Annals of Hematology, 2015, , 241-247.

[64] Clarke, C.J.; Holyoake, T.L. Preclinical approaches in chronic myeloid leukemia: from cells to systems. Exp. Hematol., 2017, 47, 13-23.

http://dx.doi.org/10.1016/j.exphem.2016.11.005 PMID: 28017647

[65] Ren, R. Mechanisms of BCR-ABL in the pathogenesis of chronic myelogenous leukaemia. Nat. Rev. Cancer, 2005, 5(3), 172-183. http://dx.doi.org/10.1038/nrc1567 PMID: 15719031

[66] Druker, B.J.; Talpaz, M.; Resta, D.J.; Peng, B.; Buchdunger, E.; Ford, J.M.; Lydon, N.B.; Kantarjian, H.; Capdeville, R.; Ohno-Jones, S.; Sawyers, C.L. Efficacy and safety of a specific inhibitor of the BCR-ABL tyrosine kinase in chronic myeloid leukemia. N. Engl. J. Med., 2001, 344(14), 10311037.

http://dx.doi.org/10.1056/NEJM200104053441401 PMID: 11287972

[67] Pophali, P. A.; Patnaik, M. M. The role of new tyrosine kinase inhibitors in chronic myeloid leukemia. Cancer J., 2016, 22(1), 40-50.

[68] Gambacorti-Passerini, C. B.; Gunby, R. H.; Piazza, R.; Galietta, A.; Rostagno, R.; Scapozza, L. Molecular mechanisms of resistance to imatinib in Philadelphia-chromosomepositive leukaemias. Lancet Oncol., 2003, 4(2), 75-85.

[69] Yu, Z.; Liu, L.; Shu, Q.; Li, D.; Wang, R. Leukemia stem cells promote chemoresistance by inducing downregulation of lumican in mesenchymal stem cells. Oncol. Lett., 2019 , 18(4), 4317-4327.

http://dx.doi.org/10.3892/ol.2019.10767 PMID: 31579426

[70] fda; cder HIGHLIGHTS OF PRESCRIBING INFORMATION,

[71] Gleevec ${ }^{\circledR}$,
[72] Ponatinib (marketed as Iclusig) Informaton | FDA https://www.fda.gov/drugs/postmarket-drug-safetyinformation-patients-and-providers/ponatinib-marketediclusig-informaton

[73] Jabbour, E.; Kantarjian, H.; Cortes, J. Use of second- and third-generation tyrosine kinase inhibitors in the treatment of chronic myeloid leukemia: an evolving treatment paradigm. Clin. Lymphoma Myeloma Leuk., 2015, 15(6), 323-334.

[74] Kim, S.G.; Kim, C.W.; Ahn, E.T.; Lee, K.Y.; Hong, E.K.; Yoo, B.I.; Han, Y.B. Enhanced anti-tumour effects of acriflavine in combination with guanosine in mice. J. Pharm. Pharmacol., 1997, 49(2), 216-222.

http://dx.doi.org/10.1111/j.2042-7158.1997.tb06783.x PMID: 9055199

[75] Hallal, R.; Nehme, R.; Brachet-Botineau, M.; Nehme, A.; Dakik, H.; Deynoux, M.; Dello Sbarba, P.; Levern, Y.; Zibara, K.; Gouilleux, F.; Mazurier, F. Acriflavine targets oncogenic STAT5 signaling in myeloid leukemia cells. J. Cell. Mol. Med., 2020, ????

http://dx.doi.org/10.1111/jcmm.15612 PMID: 32667731

[76] Sabolova, D.; Kristian, P.; Kozurkova, M. Proflavine/acriflavine derivatives with versatile biological activities. J. Appl. Toxicol., 2020, 40(1), 64-71.

http://dx.doi.org/10.1002/jat.3818 PMID: 31222780

[77] Cheloni, G.; Tanturli, M.; Tusa, I.; Ho DeSouza, N.; Shan, Y.; Gozzini, A.; Mazurier, F.; Rovida, E.; Li, S.; Dello Sbarba, P. Targeting chronic myeloid leukemia stem cells with the hypoxia-inducible factor inhibitor acriflavine. Blood, 2017, 130(5), 655-665.

http://dx.doi.org/10.1182/blood-2016-10-745588 PMID: 28576876

[78] Maxwell, P.H.; Pugh, C.W.; Ratcliffe, P.J. Activation of the HIF pathway in cancer. Curr. Opin. Genet. Dev., 2001, 11(3), 293-299.

http://dx.doi.org/10.1016/S0959-437X(00)00193-3 PMID: 11377966

[79] Deynoux, M.; Sunter, N.; HA(c)rault, O.; Mazurier, F. Hypoxia and Hypoxia-Inducible Factors in Leukemias. Front. Oncol., 2016, 6(FEB), 41.

http://dx.doi.org/10.3389/fonc.2016.00041 PMID: 26955619

[80] Majmundar, A.J.; Wong, W.J.; Simon, M.C. Hypoxiainducible factors and the response to hypoxic stress. Mol. Cell, 2010, 40(2), 294-309.

http://dx.doi.org/10.1016/j.molcel.2010.09.022 PMID: 20965423

[81] Ng, K.P.; Manjeri, A.; Lee, K.L.; Huang, W.; Tan, S.Y.; Chuah, C.T.H.; Poellinger, L.; Ong, S.T. Physiologic hypoxia promotes maintenance of CML stem cells despite effective BCR-ABL1 inhibition. Blood, 2014, 123(21), 33163326.

http://dx.doi.org/10.1182/blood-2013-07-511907 PMID: 24705490

[82] Zhang, H.; Li, H.; Xi, H.S.; Li, S. HIF1I is required for survival maintenance of chronic myeloid leukemia stem cells. Blood, 2012, $119(11), 2595-2607$.

http://dx.doi.org/10.1182/blood-2011-10-387381 PMID: 22275380

[83] Wang, Y.; Liu, Y.; Malek, S.N.; Zheng, P.; Liu, Y. Targeting HIF1I eliminates cancer stem cells in hematological malignancies. Cell Stem Cell, 2011, 8(4), 399-411. http://dx.doi.org/10.1016/j.stem.2011.02.006 PMID: 21474104

[84] Kawada, H.; Kaneko, M.; Sawanobori, M.; Uno, T.; Matsuzawa, H.; Nakamura, Y.; Matsushita, H.; Ando, K. High concentrations of L-ascorbic acid specifically inhibit the 
growth of human leukemic cells via downregulation of HIF11 transcription. PLoS One, 2013, 8(4)e62717 http://dx.doi.org/10.1371/journal.pone.0062717 PMID: 23626851

[85] Coltella, N.; Valsecchi, R.; Ponente, M.; Ponzoni, M.; Bernardi, R. Synergistic Leukemia Eradication by Combined Treatment with Retinoic Acid and HIF Inhibition by EZN2208 (PEG-SN38) in Preclinical Models of PML-RARI? and PLZF-RARI -Driven Leukemia. Clin. Cancer Res., 2015, 21 (16), 3685-3694.

http://dx.doi.org/10.1158/1078-0432.CCR-14-3022 PMID: 25931453

[86] Chen, B-A.; Wang, F.; Cheng, J.; Ding, J-H.; Xu, W-L.; Wang, X-M.; Gao, C.; Wang, J.; Zhao, G.; Bao, W. Effect of YC-1, a HIF Inhibitor,On Apoptosis of Leukemia Cell. Blood, 2009, 114(22), 4432-4432.

http://dx.doi.org/10.1182/blood.V114.22.4432.4432

[87] Chung, J.G.; Yang, J.S.; Huang, L.J.; Lee, F.Y.; Teng, C.M.; Tsai, S.C.; Lin, K.L.; Wang, S.F.; Kuo, S.C. Proteomic approach to studying the cytotoxicity of YC-1 on U937 leukemia cells and antileukemia activity in orthotopic model of leukemia mice. Proteomics, 2007, 7(18), 3305-3317.

http://dx.doi.org/10.1002/pmic.200700200 PMID: 17849408

[88] Ajith, T. A. Current Insights and Future Perspectives of Hypoxia-Inducible Factor-Targeted Therapy in Cancer Journal of Basic and Clinical Physiology and Pharmacology, 2019, , 11-18.

[89] Tanturli, M.; Giuntoli, S.; Barbetti, V.; Rovida, E.; Dello Sbarba, P. Hypoxia selects bortezomib-resistant stem cells of chronic myeloid leukemia. PLoS One, 2011, 6(2)e17008 http://dx.doi.org/10.1371/journal.pone.0017008 PMID: 21347297

[90] Sullivan, R.; ParA(c), G.C.; Frederiksen, L.J.; Semenza, G.L.; Graham, C.H. Hypoxia-induced resistance to anticancer drugs is associated with decreased senescence and requires hypoxia-inducible factor-1 activity. Mol. Cancer Ther., 2008, 7(7), 1961-1973.

http://dx.doi.org/10.1158/1535-7163.MCT-08-0198 PMID: 18645006

[91] Shuai, K.; Halpern, J.; ten Hoeve, J.; Rao, X.; Sawyers, C.L. Constitutive activation of STAT5 by the BCR-ABL oncogene in chronic myelogenous leukemia. Oncogene, 1996, 13(2), 247-254.

PMID: 8710363

[92] Warsch, W.; Kollmann, K.; Eckelhart, E.; Fajmann, S.; Cerny-Reiterer, S.; HAlbl, A.; Gleixner, K.V.; Dworzak, M.; Mayerhofer, M.; Hoermann, G.; Herrmann, H.; Sillaber, C.; Egger, G.; Valent, P.; Moriggl, R.; Sexl, V. High STAT5 levels mediate imatinib resistance and indicate disease pro- gression in chronic myeloid leukemia. Blood, 2011, 117(12), 3409-3420.

http://dx.doi.org/10.1182/blood-2009-10-248211 PMID: 21220747

[93] Houshmand, M.; Simonetti, G.; Circosta, P.; Gaidano, V.; Cignetti, A.; Martinelli, G.; Saglio, G.; Gale, R. P. Chronic Myeloid Leukemia Stem Cells / Leukemia, 2019, , 15431556.

[94] Brachet-Botineau, M.; Polomski, M.; Neubauer, H. A.; Juen, L.; HA(c)dou, D.; Viaud-Massuard, M. C.; PriA(c), G.; Gouilleux, F. Pharmacological Inhibition of Oncogenic STAT3 and STAT5 Signaling in Hematopoietic Cancers Cancers, 2020,

[95] Pimozide Oral: Uses, Side Effects, Interactions, Pictures, Warnings \& \&osing https:/www.webmd.com/drugs/2/drug-11062/pimozideoral/details

[96] Nelson, E.A.; Walker, S.R.; Weisberg, E.; Bar-Natan, M.; Barrett, R.; Gashin, L.B.; Terrell, S.; Klitgaard, J.L.; Santo, L.; Addorio, M.R.; Ebert, B.L.; Griffin, J.D.; Frank, D.A. The STAT5 inhibitor pimozide decreases survival of chronic myelogenous leukemia cells resistant to kinase inhibitors. Blood, 2011, 117(12), 3421-3429.

http://dx.doi.org/10.1182/blood-2009-11-255232 PMID: 21233313

[97] Bar-Natan, M.; Nelson, E. A.; Walker, S. R.; Kuang, Y.; Distel, R. J.; Frank, D. A. Dual Inhibition of Jak2 and STAT5 Enhances Killing of Myeloproliferative Neoplasia Cells Leukemia, 2012, , 1407-1410.

[98] Yun, U.J.; Park, S.E.; Jo, Y.S.; Kim, J.; Shin, D.Y. DNA damage induces the IL-6/STAT3 signaling pathway, which has anti-senescence and growth-promoting functions in human tumors. Cancer Lett., 2012, 323(2), 155-160. http://dx.doi.org/10.1016/j.canlet.2012.04.003 PMID: 22521547

[99] Wang, L.; Niu, M.; Zheng, C.; Zhao, H.; Niu, X.; Li, L.; Hu, Y.; Zhang, Y.; Shi, J.; Zhang, Z. A Core-Shell Nanoplatform for Synergistic Enhanced Sonodynamic Therapy of Hypoxic Tumor via Cascaded Strategy. Adv. Healthc. Mater., 2018, 7(22)e1800819

http://dx.doi.org/10.1002/adhm.201800819 PMID: 30303621

[100] Zeng, M.; Shen, J.; Liu, Y.; Lu, L.Y.; Ding, K.; Fortmann, S.D.; Khan, M.; Wang, J.; Hackett, S.F.; Semenza, G.L.; Campochiaro, P.A. The HIF-1 antagonist acriflavine: visualization in retina and suppression of ocular neovascularization. J. Mol. Med. (Berl.), 2017, 95(4), 417-429. http://dx.doi.org/10.1007/s00109-016-1498-9 PMID: 28004126

DISCLAIMER: The above article has been published in Epub (ahead of print) on the basis of the materials provided by the author. The Editorial Department reserves the right to make minor modifications for further improvement of the manuscript. 